\title{
Inibidores da Proteína Auxiliar Nef do Vírus HIV-1: um Novo Alvo Terapêutico no Tratamento da SIDA
}

\author{
Carlos E. M. Salvador, Lucília Z. A. Corrêa \& Carlos K. Z. Andrade
}

Após vários anos do estabelecimento da terapia antirretroviral, o desenvolvimento científico da SIDA encontra-se em uma encruzilhada devido ao surgimento de novos paradigmas, entre os quais se destacam o aparecimento de variantes resistentes a inibidores presentes no coquetel antirretroviral; a permanência de reservatórios virais latentes; a presença de efeitos tóxicos colaterais causados pelo tratamento e o alto custo das drogas disponíveis no mercado. A degradação do receptor CD4 na superfície das células infectadas promovida pela ação da proteína auxiliar Nef do vírus HIV-1 é decisiva para a promoção da infectividade viral. A identificação de inibidores desta função da Nef é de grande importância para o tratamento da SIDA. Neste artigo, esses aspectos serão discutidos com mias detalhes.

Palavras-chave: HIV-1, Proteína Nef, CD4, terapia antirretroviral

After several years of the establishment of antiretroviral therapy, the scientific development of AIDS is at a crossroad due to the emergence of new paradigms, among which we highlight the emergence of variants resistant to inhibitors present in the antiretroviral cocktail, the permanence of latent viral reservoirs, the presence of toxic side effects caused by the treatment and the high cost of drugs on the market. The degradation of the CD4 receptor on the surface of infected cells promoted by the action of the HIV1 auxiliary protein Nef is critical for promoting viral infectivity. The identification of inhibitors of this function of Nef is of great important in the treatment of AIDS. In this paper, these aspects will be discussed in more detail.

Keywords: HIV-1, Nef protein, CD4, antiretroviral therapy. 


\section{Introdução}

Após três décadas da descoberta do vírus HIV da Síndrome da Imunodeficiência Adquirida (SIDA) pelos pesquisadores Robert Gallo, dos EUA, e Luc Montagnier, da França ${ }^{1}$, a SIDA é protagonista de uma pandemia sem precedentes na história da humanidade, que desafia as autoridades de saúde pública em nível mundial. De acordo com o programa conjunto das Nações Unidas sobre HIV/AIDS (UNAIDS), em 2009, cerca de 33,3 milhões de pessoas encontravam-se infectadas pelo vírus HIV em todo o mundo, sendo que, deste número, 47\% são mulheres, 44,8\% são homens e $7,5 \%$ são crianças. As mortes provocadas pelo vírus HIV-1, em 2009, ultrapassam o número de 1,8 milhão de pessoas² .

Portadores do HIV podem ficar assintomáticos por vários anos e alguns nunca desenvolvem doenças oportunistas. Isso ocorre pela variabilidade genética do vírus e está diretamente relacionado com a quantidade e qualidade dos receptores CD4 na superfície das células do sistema imune. Avalia-se o grau da infecção do vírus HIV por contagem de quantidade de linfócitos T CD4 no sangue, sendo normal de 1.000 a 2.500 células/mL de sangue.

Após a infecção pelo vírus HIV-1, o vírus destrói os linfócitos CD4, baixando gradativamente a sua concentração. Em média, esse declínio é de 80 a 100 células/mL de sangue/ano. Por esse motivo, a pessoa infectada é acometida por um período aparentemente assintomático após a infecção, tempo necessário para as células do sistema imunológico serem infectadas, o que pode levar de 6 meses a 20 anos. Este período assintomático precede uma profunda disfunção do sistema imune o que, por sua vez, leva à ocorrência de diversas doenças infecciosas oportunistas (quadro conhecido como SIDA) e que, finalmente, levam à morte do paciente.

O tratamento da SIDA, e não a sua cura, é baseado no monitoramento da carga viral plasmática e na contagem de células $\mathrm{T}$ expressando CD4 e consiste na redução da carga viral, que é considerada alta acima de 100.000 cópias/mL de sangue. Seguindo-se um tratamento adequado, a carga viral tende a ficar abaixo de 50 cópias $/ \mathrm{mL}$ de sangue e o portador do vírus pode ter uma vida normal. Este monitoramento permite o tratamento preventivo da progressão da infectividade do vírus HIV-1 e é promovido pelo uso de coqueteis de fármacos antirretrovirais que auxiliam na redução da taxa viral, retardando a infecção do HIV e minimizando os danos ao sistema imunológico ${ }^{3}$. As principais consequências do uso da terapia antirretroviral (TARV) são a redução da evolução da imunodeficiência causada pelo vírus HIV-1 e o aumento da expectativa de vida do paciente infectado ${ }^{4}$. O tratamento com drogas antirretrovirais é baseado na contagem de linfócitos CD4 no sangue (Tabela 1).

Tabela 1. Contagem de linfócitos CD4 no sangue para fins de tratamento com antirretrovirais ${ }^{5}$

\begin{tabular}{|c|c|c|}
\hline Entrada & $\begin{array}{c}\text { Células/mL } \\
\text { de sangue }\end{array}$ & Estado clínico \\
\hline 1 & 200 & Muito crítico \\
\hline 2 & $200-350$ & Crítico \\
\hline 3 & $350-500$ & Pouco crítico \\
\hline 4 & $>500$ & Saudável \\
\hline
\end{tabular}

O AZT (3-azido-2,3-didesoxitimidina) foi o primeiro fármaco antirretroviral a demonstrar resultados concretos no tratamento do vírus HIV-1 (Figura 1). Os fármacos são utilizados em conjunto e são divididos em classes, uma vez que cada um dos diversos fármacos criados (Tabela 2) atua em um estágio de vida diferente do vírus ${ }^{5}$.

Ainda não é conhecido nenhum tratamento para a cura da infecção pelo vírus, nem mesmo vacinas para a prevenção. É muito difícil criar algum tipo de vacina, sendo o vírus da imunodeficiência humana um vírus com alta variabilidade genética e grande poder de mutação. Segundo Montagnier ${ }^{6}$, os esforços devem ser concentrados nos estudos da ação do vírus para assim poder ser sintetizado um fármaco. Pensar em vacina preventiva contra um vírus com tão grande variabilidade genética seria perda de tempo.

Apesar de ainda não ter sido descoberta a cura para o HIV, o tratamento antirretroviral conhecido como Haart - Highly Active Antiretroviral Therapy - tem melhorado significativamente a vida de portadores do vírus. Alguns dos fármacos utilizados no tratamento antirretroviral podem ser observados na Figura 1.

Os fármacos antirretrovirais (ARV) atuam sobre a ação da enzima viral transcriptase reversa (TR), inibindo 
Tabela 2. Classe dos fármacos disponíveis no mercado e suas funções ${ }^{5}$

\begin{tabular}{|c|c|c|}
\hline Classe & Fármaco & Função \\
\hline $\begin{array}{l}\text { Inibidores nucleosídeos da } \\
\text { transcriptase reversa }\end{array}$ & $\begin{array}{l}\text { Zidovudina (AZT), Abacavir, Didanosina, } \\
\text { Estavudina, Lamivudina e Tenofovir }\end{array}$ & $\begin{array}{l}\text { Incorporam-se à cadeia de DNA virótica, por meio da } \\
\text { enzima transcriptase reversa, tornando-a defeituosa e } \\
\text { impedindo a reprodução do vírus. }\end{array}$ \\
\hline $\begin{array}{l}\text { Inibidores não nucleosídeos da } \\
\text { transcriptase reversa }\end{array}$ & Efavirenz, Nevirapina e Etravirina & $\begin{array}{l}\text { Bloqueiam diretamente a ação da enzima } \\
\text { transcriptase reversa, impedindo a reprodução do } \\
\text { vírus. }\end{array}$ \\
\hline Inibidores de protease & $\begin{array}{l}\text { Atazanavir, Darunavir, Fosamprenavir, Indinavir, } \\
\text { Lopinavir/r, Nelfinavir, Ritonavir e Saquinavir }\end{array}$ & $\begin{array}{l}\text { Bloqueiam a ação da enzima protease, impedindo a } \\
\text { produção de novas cópias de células viróticas. }\end{array}$ \\
\hline Inibidores de fusão & Enfuvirtida & Impedem a entrada do vírus na célula. \\
\hline Inibidores da integrase & Raltegravir & $\begin{array}{l}\text { Bloqueiam a atividade da enzima integrase, que é } \\
\text { responsável pela inserção do DNA virótico ao DNA } \\
\text { da célula. }\end{array}$ \\
\hline
\end{tabular}

uma importante etapa do ciclo de vida do vírus HIV: a tradução do filamento de DNA virótico a partir do RNA viral, por meio da associação dos fármacos inibidores da trasncriptase reversa análogos de nucleosídeos (ITRN) e os fármacos inibidores da transcriptase reversa nãoanálogos de nucleosídeos (ITRNN). Esta associação se faz necessária devido à resistência do vírus à medicação.
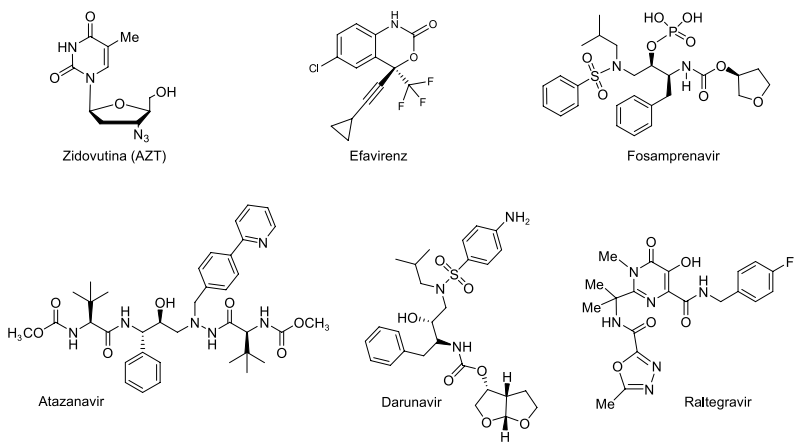

Figura 1. Estruturas de alguns fármacos antirretrovirais.

O aparecimento de variantes resistentes do vírus HIV-1, a permanência de reservatórios virais latentes, a presença de efeitos tóxicos colaterais causados pelo tratamento e o alto custo das drogas disponíveis no mercado destacam-se como novos paradigmas ao uso da $\mathrm{TARV}^{7}$. O aprofundamento no conhecimento dos mecanismos básicos de patogêneses, assim como a identificação de novos alvos terapêuticos, volta a desempenhar um papel crucial no desenvolvimento de formas inéditas de tratamento da SIDA.

\section{O CICLO REPRODUTIVO DO VÍRUS HIV-1}

A SIDA é provocada pela ação do vírus HIV-1 em células hospedeiras do tipo macrófagos ou linfócitos T. Todas estas células possuem em sua membrana plasmática a presença do receptor glicoproteico CD4. Por meio da interação da glicoproteína viral gp120 com o CD4, presente na superfície da célula, o vírus HIV-1, que pertence à família dos retrovírus, é transfectado para o interior da célula, onde o seu RNA viral serve como padrão para a transcrição de um filamento de DNA viral $^{8}$. A transcrição do filamento de DNA viral a partir do RNA virótico é catalisada pela ação da enzima viral transcriptase reversa e por enzimas da célula hospedeira. Após a transcrição, o DNA viral é transportado para o núcleo da célula infectada, onde é incorporado ao material genético da célula hospedeira por meio da ação da enzima integrase viral. Após a integração ao DNA da célula hospedeira, o DNA viral é transcrito em RNA mensageiro, que coordena a síntese de proteínas virais, o que posteriormente dará origem a um novo vírus capaz de infectar outra célula9 .

\section{A ESTRUTURA DA PROTEÍNA AUXILIAR NEF}

A proteína Nef possui de 27 a $37 \mathrm{kDa}$ e um comprimento de 206 a 210 resíduos de aminoácidos. Em todas as espécies de Nef, independente do tipo de vírus da imunodeficiência, ocorre a fosforilação do grupo mirístico e dos seis primeiros resíduos do $N$-terminal da Nef ( $N$-miristoilação $)^{10}$. A $N$-miristoilação da Nef permite sua fixação nas membranas celulares 
(Figura 2), indispensáveis para a realização de todas as funções biológicas da Nef citadas anteriormente e, principalmente, na promoção da modulação negativa do CD4. Para melhorar a capacidade da modulação negativa do CD4 pela Nef, resíduos de serina e treonina são também fosforilados ${ }^{11}$. A combinação de estudos de cristalografia de raios-X e espectroscopia de ressonância magnética nuclear (RMN) permitiram a elucidação de grande parte da estrutura tridimensional da proteína Nef do vírus HIV (Figura 3) ${ }^{12}$. Estes estudos revelam a existência de várias regiões importantes para a interação com fatores celulares do tipo tioesterase: CD4; V1H; proteínas adaptadoras de clatrina, PAK 1, PAK 2, Vav (SH3), Lck (SH3), Hck (SH3); e possivelmente $\beta$-Cop (Figura 4). No resíduo $1-80$ da proteína Nef, temos a região $N$-terminal flexível, na qual podemos destacar a presença de uma região ácida (resíduos 62 - 65) e um tipo de hélice poliprolina (resíduos 68 - 69). Entre os resíduos 81 - 147 e 181 - 202, encontramos a região C-terminal (domínio central) e entre os resíduos 148 180, uma região bem exposta e flexível (loop). Nesta região, podemos destacar os motivos dileucina (resíduos 160 - 165) e di-aspártico (resíduos 154 - 155) ${ }^{13}$.

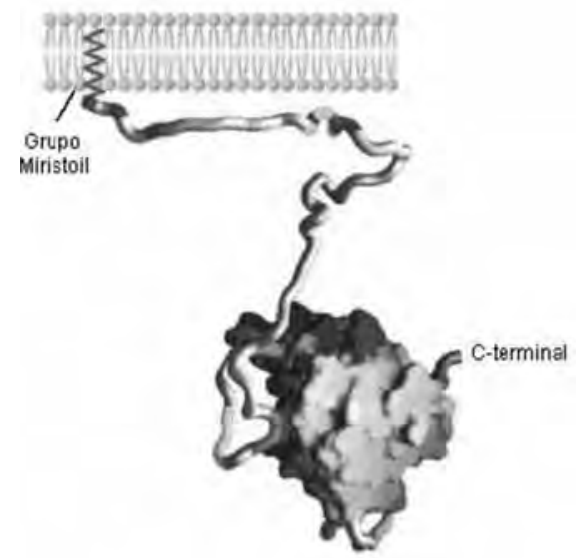

Figura 2. Representação da Proteína Nef associada à membrana plasmática pelo grupo Miristoíla ${ }^{10}$

Cálculos demonstram que a superfície total de exposição dos domínios da proteína Nef do vírus HIV-1 é de 17.600 Å. Em comparação com outras proteínas de 206 resíduos, a Nef possui uma área aproximadamente $57 \%$ maior de exposição de seus domínios ${ }^{14}$. A combinação da elevada área de exposição e domínios flexíveis possibilitam à Nef realizar um grande número de interações com diferentes substratos, o que pode justificar as inúmeras funções importantes executadas pela Nef no ciclo de vida do vírus HIV.

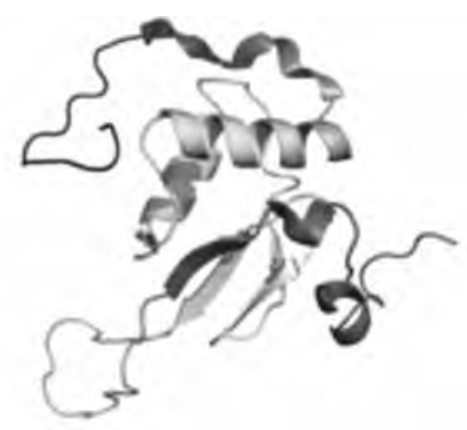

Figura 3. Representação tridimensional da Proteína Nef

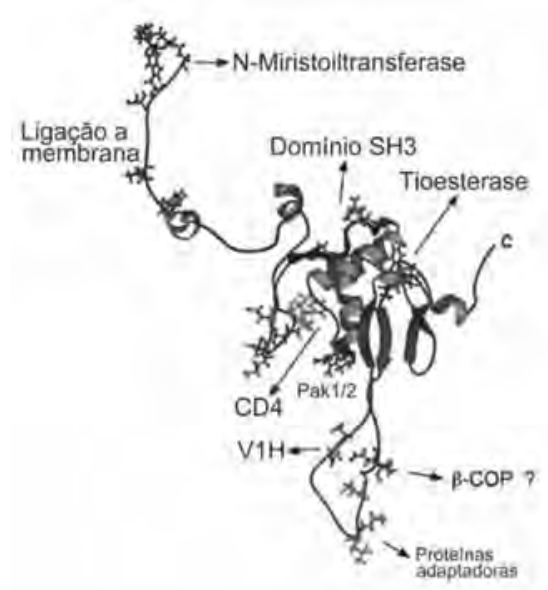

Figura 4. Regiões da proteína auxiliar Nef do vírus HIV-1 que interagem com diferentes substratos celulares ${ }^{12}$

\section{A MODULAÇÃO NEGATIVA DO CD4 MEDIADA PELA NEF}

Recentes evidências mostram claramente que a molécula CD4 exerce dois efeitos opostos durante a infecção pelo vírus da imunodeficiência humana (HIV1). Na fase inicial, o receptor viral é requerido para a entrada do vírus na célula hospedeira. Entretanto, na fase tardia, o CD4 exerce um potente efeito inibitório em duas importantes etapas do ciclo viral, inibindo a infectividade e a liberação das partículas virais ${ }^{15}$. A diminuição da expressão do receptor CD4 na superfície 
das células infectadas é um dos mais importantes eventos durante a infecção pelo HIV-1, sendo conservada tanto nos retrovírus da imunodeficiência humana (HIV-1, HIV-2) como na imunodeficiência simiana (SIV) ${ }^{16}$. Três proteínas auxiliares do vírus HIV-1 participam deste fenômeno: Nef, Vpu e Env, sendo a Nef a mais relevante. A Nef aumenta a internalização das moléculas de CD4 expressas na superfície celular, enquanto as proteínas Vpu / Env redirecionam as moléculas de CD4 recémsintetizadas para degradação lisossômica (Figura 5) ${ }^{16}$. Lama e colaboradores ${ }^{16}$ demonstraram que o seletivo bloqueio da degradação de CD4 mediada por Nef inibe a infectividade e a replicação viral em células de sangue periférico. Isto se deve ao fato de que o CD4, presente na superfície da membrana plasmática viral, é incorporado na partícula viral, no momento da eliminação, o que provavelmente ocorre por associação com a gp120, interferindo na ligação do envelope aos receptores da célula-alvo.

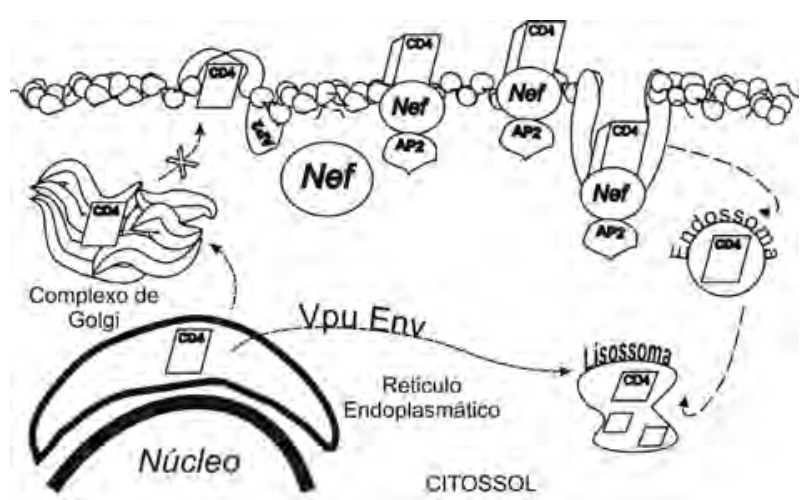

Figura 5. Modulação Negativa do CD4 por Nef, Vpu e Env (adaptada da ref. 13)

\section{A IMPORTÂNCIA DA PROTEÍNA AUXILIAR NEF PARA O CICLO DE VIDA DO VÍRUS HIV}

A Nef é uma proteína auxíliar do vírus HIV-1, de importância fundamental no avanço da patogenia da SIDA. Esta relevância é demonstrada por estudos com pacientes que mesmo após a infecção levaram 10 anos para desenvolverem os sintomas da $\operatorname{SIDA}^{17}$. Estes pacientes possuíam uma espécie de vírus HIV que não produzia a proteína Nef. Pesquisas desenvolvidas com a infecção de ratos com o HIV-1 humano demonstraram que os vírus que foram incapazes de expressar a proteína
Nef possuíam uma menor infectibilidade, indicando uma direta relação entre a expressão da Nef e a virulência do vírus HIV-18.

As inúmeras funções atribuídas à proteína auxíliar Nef justificam a sua influência na replicação e no desenvolvimento da SIDA. Dentre estas funções, a regulação dos níveis de concentração das moléculas de CD4 na membrana plasmática é a mais determinante para a replicação e patogenicidade do vírus HIV.

\section{INIBIDORES DE NEF}

Os avanços registrados na literatura sobre o entendimento do mecanismo de ação da Nef na modulação negativa do CD4, localizado na superfície da membrana plasmática, sugerem um importante papel da Nef na replicação do vírus HIV e no desenvolvimento da SIDA. A restauração dos níveis de CD4 na superfície de células infectadas pode inibir a formação de partículas infecciosas do vírus HIV, contribuindo na diminuição da taxa de propagação do vírus. A restauração da concentração dos níveis de CD4 na membrana plasmática das células infectadas permite que a célula infectada retome algumas funções normais, perdidas pela degradação do CD4 em células $\mathrm{T}^{19}$. A primeira etapa da internalização do CD4 mediada por Nef tem como consequência o surgimento de inúmeras pequenas depressões na membrana plasmática recobertas pela proteína fibrosa clatrina ${ }^{20}$. Dessa forma, a Nef realiza a ponte entre o CD4 e o maquinário celular da via endocítica para a digestão celular ${ }^{21}$.

Com base nesta proposta mecanística para a modulação negativa do CD4 pela Nef, Luo e colaboradores ${ }^{22}$ propuseram que inibidores de endocitose mediada por receptores proteicos poderiam bloquear a primeira etapa de ação da proteína viral Nef e, consequentemente, restabelecer o CD4 na membrana plasmática das células infectadas pelo vírus HIV. Desta maneira, para compreender melhor o mecanismo de interação entre a Nef e a via endocítica, foram testados inúmeros agentes inibidores de diferentes etapas da via endocítica. No entanto, a maioria desses agentes testados promovia o bloqueio da degradação de CD4 em células que expressam a Nef, mas não permitiam a recuperação do CD4 na superfície celular ${ }^{23}$. Dentre os compostos testados, o antibiótico macrocíclico Ikarugamicina (Figura 6) promoveu o aumento da meia-vida do CD4 na 
presença da Nef e a recuperação significativa da expressão do CD4 na superfície das células. O restabelecimento dos níveis de CD4 na membrana plasmática não foi consequência da diminuição dos níveis de Nef expressos pelas células infectadas, mas, sim, pela alteração do mecanismo de transporte do CD4 pela via endocítica ${ }^{22}$.

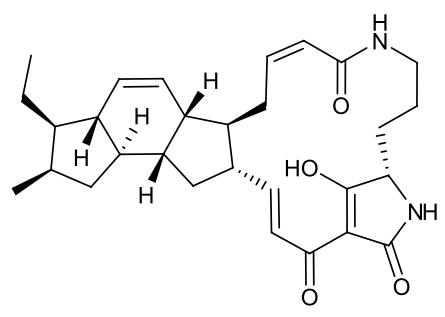

Figura 6. Antibiótico Ikarugamicina ${ }^{23}$

A Ikarugamicina restabelece a expressão de CD4 em células expressando a proteína Nef e também bloqueia a degradação do CD4 induzido pelo tratamento com acetato de forbol miristato (PMA), o que poderia gerar distúrbios das funções celulares normais e efeitos colaterais indesejados, impedindo, assim, sua utilização in vivo ${ }^{24}$. Apesar de ser citotóxica por inibir a expressão de CD4 pela célula, a Ikaguramicina pode ser utilizada no desenvolvimento de estudos teóricos das características da interação entre o CD4 e a Nef.

A descrição topográfica estrutural da proteína Nef do vírus HIV-1 destaca a presença do motivo A56W57L58 como uma importante região para a modulação negativa do CD4 pela $\mathrm{Nef}^{13}$ e, vizinho a este motivo, localizamos dois resíduos da proteína cisteína, o Cys206 e o Cys55. A alquilação de um grupo volumoso nestes resíduos próximos ao motivo A56W57L58 promove modificações estruturais nesta região da proteína viral Nef, importante para a interação com o $C D 4^{13}$. Jin e colaboradores $^{25}$ recentemente utilizaram reagentes de alquilação de peptídeos, TPCK (clorometil $N$-1-p-tosila$L$-fenilalanina cetona) e TLCK (clorometil Nap-tosila- $L$ lisina cetona), com o objetivo de desenvolver uma nova classe de inibidores da proteína auxíliar Nef (Figura 7). Os reagentes TPCK e TLCK são agentes alquilantes específicos de protease ${ }^{26}$. O uso destes reagentes permitiu a esses pesquisadores promoverem mudanças estruturais significativas na proteína viral Nef devido às ligações covalentes do TPCK e TLCK nos resíduos
Cys55 e Cys206, nas cadeias laterais da proteína Nef. Esta modificação conformacional da proteína viral Nef devido ao acoplamento dos reagentes TPCK e TLCK inibiu significativamente a interação da Nef com o CD4. Porém, estes agentes promoveram a alquilação de metade da concentração da Nef em cultura de células T, não inibindo assim a modulação negativa do CD4, devido ao fato de que uma pequena quantidade da proteína viral Nef é suficiente para promover a degradação do CD4. Além disso, o aumento das concentrações dos reagentes alquilantes TPCK e TLCK demonstrou citotoxidade, o que comprometeu os testes de atividade in vivo ${ }^{25}$.
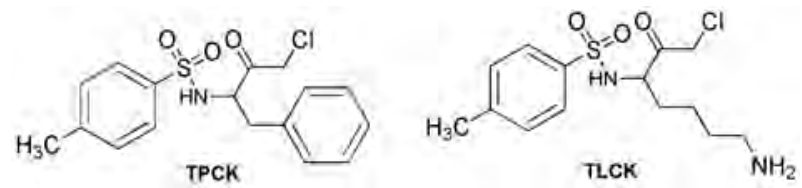

Figura 7. Reagentes de alquilação de peptídeos, TPCK (clorometil Nap-tosila-L-fenilalanina cetona) e TLCK (clorometil Nap-tosila-Llisina cetona $)^{26}$

A interação com diversos substratos celulares realizada pela proteína viral Nef, independente da ação enzimática, é decorrente da elevada flexibilidade de seus sítios catalíticos e das interações frágeis estabelecidas pela Nef com seus substratos celulares ${ }^{27}$. Estas características aumentam o desafio do desenvolvimento de antagonistas da Nef que não apresentem citotoxidade $^{28}$. Em uma tentativa de minimizar os efeitos colaterais apresentados devido às características descritas anteriormente, Breuer e colaboradores ${ }^{29}$ propuseram uma metodologia baseada no estudo das interações existentes entre a proteína auxiliar Nef do vírus HIV-1 e os diferentes elementos do maquinário celular envolvidos na degradação do CD4. Esta nova abordagem foi denominada de "envolvimento da proteína Nef”. Nesta estratégia, são promovidas inúmeras interações simultâneas com sítios catalíticos variáveis da proteína viral Nef, visando assim ao envolvimento da superfície da Nef e à inibição simultânea das diferentes funções atribuídas à $\mathrm{Nef}^{30}$.

A correlação entre estrutura e função da proteína $\mathrm{Nef}^{13}$ permitiu a Breuer e colaboradores selecionarem os domínios de interação de substratos celulares e as sequências de sinal lipídicas importantes para a síntese de inibidores por envolvimento da proteína viral. Estes 
elementos selecionados foram acoplados no meio intracelular em várias combinações, gerando quatro gerações de proteínas de fusão NI. Estas proteínas permitiram uma maior afinidade e especificidade com os sítios catalíticos da proteína viral Nef, inibindo a degradação do $\mathrm{CD}_{4}{ }^{31}$. Estes resultados comprovaram que a ação da proteína viral Nef necessita de diferentes fatores independentes e que a inibição destes fatores anula a infectividade do vírus HIV-1. Apesar da ausência de citotoxidade, o uso de anti-infecciosos com base na expressão intracelular de proteínas inibidoras NI apresenta limitações farmacocinéticas que impedem a sua exploração terapêutica no combate à infecção pelo vírus HIV $^{32}$.

\section{PLANEJAMENTO RACIONAL DE UMA NOVA CLASSE DE INIBIDORES DA PROTEÍNA AUXILIAR NEF DO VÍRUS HIV-1}

O conhecimento da topografia molecular tridimensional da Nef e a definição de seus resíduos e motivos responsáveis pela degradação do $\mathrm{CD} 4^{13}$, disponibilizados no banco de dados PDB (Protein Data Bank), possibilitam a realização de estudos de interação por homologia entre a proteína viral Nef e os diferentes alvos terapêuticos. Estes estudos estabelecem padrões energéticos importantes para uma abordagem direta e indireta na utilização das técnicas de modelagem molecular para o planejamento racional de possíveis moléculas inibidoras da proteína Nef do vírus HIV-1. Recentemente, o nosso grupo de pesquisa desenvolveu estudos de interação por homologia entre a proteína viral Nef e o antibiótico Ikarugamicina (Figura 8) ${ }^{33}$. Estes estudos permitiram o planejamento de um conjunto de possíveis inibidores da internalização do CD4 mediada pela Nef, que no momento estão sendo sintetizados em nosso laboratório. Futuramente, as moléculas obtidas serão submetidas a testes farmacológicos para verificar sua eficiência como inibidores da proteína auxiliar Nef.

\section{Conclusão}

Os avanços observados na literatura sobre o entendimento do mecanismo de ação da proteína auxiliar Nef na modulação negativa do CD4, localizado na superfície da membrana plasmática, demonstram a importância da Nef no ciclo de vida do vírus HIV e na evolução da SIDA. A restauração dos níveis de CD4 na superfície de células infectadas provoca a inibição do surgimento de partículas infecciosas do vírus HIV, reduzindo desta maneira, a taxa de infectividade viral. A restauração da concentração dos níveis de CD4 na membrana plasmática das células infectadas retoma algumas funções normais da célula, perdidas pela degradação do $\mathrm{CD} 4$ em células T. A identificação de novas moléculas inibidoras da degradação de CD4, mediada pela proteína Nef do vírus HIV-1, pode contribuir de forma significativa no desenvolvimento de uma importante terapia para o tratamento da SIDA.
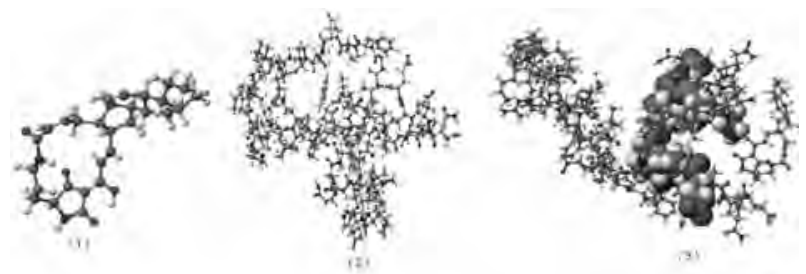

Figura 8. (1) Ikarugamicina; (2) Resíduos de interesse da proteína Nef; (3) Complexo de Nef: os resíduos de interesse para a degradação do CD4 da Nef interagindo com a Ikarugamicina ${ }^{33}$

\section{Referências}

1. Kuby, J.; Immunology, $5^{\text {th }}$ ed., W. H. Freeman and company, New York, 2003.

2. http://vacinadaaids.wordpress.com/2010/05/24/estimativa-pelomundo, acessada em 15 de janeiro 2011.

3. Cihlar, T.; Ray, A. S.; Antiviral Res. 2010, 85, 39.

4. http://whqlibdoc.who.int/hq/2004/WHO_HTM_TB_2004.329_ por_chap11.pdf, acessada em 15 de janeiro de 2011.

5. http://www.aids.gov.br/pagina/quais-sao-os-antirretrovirais, acessado em 4 de outubro de 2011.

6. http://www.europarl.europa.eu/sides/ getDoc.do?language=pt\&type=IMPRESS\& reference $=20090403 S T O 53400$, acessado em 13 de outubro de 2011.

7. Cortes, M. J.; Wong-Staal, F.; Lama J.; J. Biol. Chem. 2000, 3, 1770 .

8. Gómez, C.; Hope, J, T.; Cell Microbiol. 2005, 7, 621.

9. Márques, N.; Sancho, R.; Macho, A.; Moure, A.; Masip, I.; Messenguer, A.; Munoz, E.; Biochem. Pharmacol. 2006, 71, 596.

10. Arold, S. T.; Baur, A. S.; Trends Biochem. Sci. 2001, 26, 356. 
11. Lu, T.; Downing, J. R.; Garcia, J. V.; J. Virol. 1997, 71, 2535.

12. Grzesiek, S.; Bax, A.; Clore, G. M.; Gronenborn, J. S.; Kaufman, J.; Nat. Struct. Biol. 1996, 3, 340.

13. Grzesiek, S.; Bax, A.; Kaufman, J.; Palmer, I.; Tjandra, N.; Protein Sci. 1997, 6, 1248.

14. Geyer, M.; Facker, O. T.; Peterlin, B. M.; EMBO Reports 2001, 21,580 .

15. Ross, T. M.; Oran, A. E.; Cullen, B. R.; Curr. Biol. 1999, 9, 613.

16. Argañaraz, E. R.; Schindler, M.; Kirchhoff, F.; Cortes, M. J.; Lama, J.; J. Biol. Chem. 2003, 278, 33912.

17. Pham, H. M.; Argañaraz, E. R.; Groschel, B.; Trono, B.; Lama, J.; J. Virol. 2004, 78, 13072.

18. Deacon, N. J.; Tsykin, A.; Solomon, A.; Smith, K.; LudfordMenting, M.; Hooker, D. J.; McPhee, D. A.; Greenway, A. L.; Ellett, A.; Chatfield, C.; Lawson, V. A.; Crowe, S.; Maerz, A.; Sonza, S.; Learmont, J.; Sullivan, J. S.; Cunningham, A.; Dwyer, D.; Dowton, D.; Mills, J.; Science 1995, 270, 988.

19. Benson, R. E.; A. Sanfridson, J. S.; Ottinger, C.; Cullen, B. R.; J. Exp. Med. 1993, 177, 1566.

20. Foti, M. A.; Mangasarian, V.; Piguet, D. P.; Lew, K. H.; Krause, D.; J. Cell Biol. 1997, 139, 37.

21. Lu, X.; Brodsky F. M.; Peterlin. B. M.; Immunity 1998, 8, 647.

22. Luo, T.; Fredericksen, B. L.; Hasumi, T.; Endo, K.; Garcia, J. V.; J. Virol. 2001, 75, 2488.

23. Luo, T.; Anderson, S. J.; Garcia, J. V.; J. Virol. 1996, 70, 1527.

24. Greenberg, M. E.; EMBO J. 1997, 23, 6964.

25. Jin, J. Y.; Zhang, X.; Cai, C. Y.; Burakoff, C. J.; AIDS Res. Ther. 2010, 7, 26.
26. Lalou, C. I.; Lederer, F.; Biochimie 1993, 75, 443.

27. Geyer, M.; Facker, O. T.; Peterlin, B. M.; EMBO Reports 2001, 21, 580.

28. Dikeakos, J. D.; Atkins, K. M.; Thomas, L.; Emert-Sedlak, L.; Byeon, I. J.; Mol. Biol. Cell 2010, 21, 3279

29. Breuer, S.; Schievink, I. S.; Schulte, A.; Blankenfeldt, W.; Fackler, O. T.; Geyer, M.; Plosone 2011, 6, 1.

30. Fackler, O. T.; Moris, A.; Tibroni, N.; Giese, S. I.; Glass, B.; Virology 2006, 351, 322.

31. Arkin, M. R.; Wells, J. A.; Nat. Rev. Drug Discov. 2004, 3, 301.

32. Yamamoto, T.; Samri, A.; Marcelin, A. G.; Mitsuki, Y. Y.; Vincent, C.; AIDS 2009, 23, 2265.

33. (a) Salvador, C. E. M.; Dissertação de Mestrado, Universidade de Brasília, 2011. (b) Salvador, C. E. M.; Andrade, C. K. Z.; Martins, J. B. L.; 33 Reunião Anual da SBQ, 2010.

\section{Carlos E.M. Salvador, Lucília Z. A. Corrêa \& Carlos K. Z. Andrade*}

Laboratório de Química Metodológica e Orgânica Sintética (LaQMOS), Instituto de Química, Universidade de Brasília, CP-4478, CEP 70910970 Brasília/DF, Brasil .

*e-mail: ckleber@unb.br 